\title{
Legal Aspects of the Implementation of a Pledge of a Bill of Lading as a Security: National Legal Realities
}

\author{
Mykola K. Haliantych ${ }^{1,{ }^{*}}$, Anatoliy V. Kostruba ${ }^{2}$ and Nataliia I. Maydanyk ${ }^{3}$ \\ ${ }^{1}$ Department of Private Law Research Methodology, Academician F.H. Burchak Scientific and Research \\ Institute of Private Law and Entrepreneurship of the National Academy of Legal Sciences of Ukraine, Kyiv, \\ Ukraine \\ ${ }^{2}$ Department of Civil Law, Vasyl Stefanyk Precarpathian National University, Ivano-Frankivsk, Ukraine \\ ${ }^{3}$ Department of Civil and Labour Law, Kyiv National Economic University named after Vadym Hetman, Kyiv, \\ Ukraine
}

\begin{abstract}
The purpose of this article is a detailed study of the legal aspects of the implementation of the bill of lading in the context of the peculiarities of state legislation. Since the bill of lading is a security that gives the owner the legal authority to receive the goods, it can be accepted as collateral, as it is supported by a specific material value - its market value. At the moment, the problem of the bill of lading in the realities of Ukraine has become particularly relevant, as the world economy is now on the brink of crisis due to external factors, and the market needs additional investment, financing, budget expansion at various structural levels crisis. The methods used in the study are an analysis of the relevant legislation of Ukraine and Germany, as well as a comparative analysis, which leads to a vision of the lack of relevant functionalities in particular legislation. As a result of research, the authors found out whether the national conditions for obtaining a pledge under the bill of lading are favourable and what problems a legal entity may face in the case of this procedure. In conclusion, a number of additions were made that would need to be added to the actual legislation to facilitate the procedure for issuing funds secured by a bill of lading.
\end{abstract}

Keywords: Civil legislation, pledger, pledgee, deposit, undocumented bill of lading.

\section{INTRODUCTION}

Proper performance of obligations implies that the parties involved in a binding legal relationship, perform their duties in strict accordance with the law, the contract, and in the absence of such instructions - with the requirements that are usually imposed on performance, and hence - with business practices that have developed in commercial practice. A proper fulfilment of obligations stimulates the strengthening of the property position of the participants in these relations, the formation of their confidence in the implementation of the tasks and, ultimately, stabilises the overall civil turnover. It is the purpose of the proper performance of the obligation that governs the various means of securing them. Thus, in order to properly fulfil the obligation of one of the parties to the contract, certain means are used to ensure its implementation. Means of securing the fulfilment of obligations are understood as special property conditions established by law or contract, which stimulate the proper fulfilment of obligations by a debtor by establishing additional guarantees of satisfaction of creditors' claims (Netishinskaya et al. 2018).

*Address correspondence to this author at the Academician F.H. Burchak Scientific and Research Institute of Private Law and Entrepreneurship of the National Academy of Legal Sciences of Ukraine, Kyiv, Ukraine;

Tel: +38(044)5328558; E-mail: haliantych6442-2@uoel.uk
One of the means of securing the fulfilment of obligations is a pledge. According to Article 1 of the Law of Ukraine "On Pledge", by virtue of the pledge, a creditor (pledgee) has the right in case of default by a debtor (pledger) secured by the pledge obligation to obtain satisfaction from the value of the pledged property mainly to other creditors. Pledge arises by virtue of a contract or law (Civil Code of Ukraine 2003; Law of Ukraine... 1992). But the main source of collateral is the contract. One type of pledge is the pledge of securities. The civil legislation of Ukraine does not contain special rules on the pledge of such a type of security as a bill of lading, so when determining the subject of the pledge when the bill of lading should be approached from the positions enshrined in the new Civil Code of Ukraine (2003) and the Law of Ukraine No. 2654-XII "About the pledge" (1992). It is worth noting that the features of the bill of lading as security are determined by the following: the specifics of the subject of the contract, which is the relationship of cargo and bill of lading; special requirements for the form of the contract; features of registration of transfer of the bill of lading on a pledge.

When considering the legal relationship of the pledge, special attention should be paid to the subject of the pledge agreement. In general, the subject of the pledge is a property. However, as one of the varieties of the subject of the pledge, established by the Law of 
Ukraine "On Pledge" are securities in general, and the bill of lading in particular (Civil Code of Ukraine 2003). The peculiarity of the subject of the bill of lading agreement is not only the bill of lading itself as an object of civil law but also the property rights to the property enshrined in the bill of lading. In accordance with Articles 1, 5, 16 of this Law, the right of pledge arises from the moment of concluding the pledge agreement. If the subject of the pledge in accordance with the law or the contract must be in possession of the pledgee, the right of pledge arises at the time of transfer of the subject of the pledge. If such a transfer was made before the conclusion of the contract - then from the moment of its conclusion. If a subject of the pledge is movable property, the registration of the pledge is not associated with the moment the right of pledge arises (Law of Ukraine... 1992).

The pledge agreement of the bill of lading must be concluded in writing, by drawing up a separate document. In the practice of securities circulation, the transfer of security as a pledge is carried out according to a special full transfer inscription - a pledging endorsement. Legal issues related to the use of pledging endorsement have already been studied in modern civil studies, in particular by V. Belov (1996), O. Vyhovsky (2003), L. Netishinskaya et al. (2018), L. Novoselova (2004), L. Dobrynina (1998), A. Makovskaya (2000), B. Soyer (2016), Y. Baatz (2020), A. Pratt and J. Templeman (2018), M. Goldby (2008), Zh. Ning (2003), T. Schmitz (2011), S. Wunderlich and D. Saive (2020), L. Biswas (2011), M. Dubovec (2006), R. Aikens et al. (2015), M. Spanjaart (2018), G. Zekos (2018), and a number of other researchers. However, some aspects are controversial. First of all, it concerns the registration of relations related to the transfer of securities as collateral. This indicates the relevance of the study of the issue of registration of collateral (Vyhovsky 2003).

In theoretical research on this issue, there is a point of view on the pledging endorsement as the only legal basis for the emergence of mortgage relations. However, a number of scholars emphasise the advisability of drawing up a pledge agreement in addition to the pledging endorsement. It is generally accepted that a pledging endorsement is the only means of the pledge of securities, in which the conclusion of a separate pledge agreement does not make sense (Belov 1996). A close position on this issue is taken by A. Gabov (1999), substantiating the position that the pledge of securities arises on the basis of the pledging endorsement, which is only a special form of pledge due to certain differences compared to the general civil rules of the pledge. E. Krasheninnikov (1999) defended the opposite point of view. He believes that in order for the right of pledge on securities to arise, in addition to drawing up a pledging endorsement, a pledge agreement is required. It is seen that the point of view of $E$. Krashennikov most accurately reflects the essence of the legal relationship of the bill of lading.

\section{CHARACTERISTICS OF ENDORSEMENT AS A LEGAL CONSTRUCTION OF REGULATION OF RELATIONS OF BILL OF LADING}

An analysis of the relevant provisions of German law governing the transfer of securities as collateral shows the following. According to the Bill of Law of Germany dated June 21, 1933, the following conditions are necessary for the occurrence of a lien: the existence of an obligation to be secured, the conclusion of a pledge agreement, the performance of a pledging endorsement and the physical transfer of security (Budilov 1993). Thus, the German legislature is in favour of recognising the pledge agreement as a binding legal fact that determines the emergence of a mortgage relationship. Consider the relationship between the pledge agreement and the pledging endorsement in more detail.

First, the pledging endorsement and the pledge and securities agreement are independent elements of the relationship establishing the right of pledge on securities. Each of them is the next stage in the legal relationship of the pledge of securities. On the basis of the pledge agreement, the legal relations of the pledge of securities are established, while based on a pledging endorsement the legal registration of the fact of transfer of the security in the pledge is carried out. Secondly, by means of endorsement, the bill of lading is transferred from an endorser to an endorsee. As can be seen, the endorsement is a legal structure by which the regulation of the bill of lading is regulated. Thus, an endorsee is an independent subject of legal relations related to the circulation of the bill of lading, and not any other.

Third, the pledge of the bill of lading, which arises on the basis of the pledging endorsement, has certain differences from the general civil rules of the pledge. They are determined by means of identification, the form of the transaction, the rights of the pledgee, the satisfaction of rights in case of non-performance of the obligation secured by the pledge, etc. (Gabov 1999). 
Fourth, a pledging endorsement is an endorsement that contains only a "pledge notice". The norms of the legislation governing the circulation of the bill of lading, as well as the conditions of the bill of lading do not contain any rules governing the legal relations related to the pledge of the bill of lading. And this is not accidental, because the relations arising by virtue of the pledging endorsement and executed by such endorsement, by their legal nature are not mortgage legal relations. This suggests that the term "pledge" in the civil law of Ukraine, which regulates the circulation of a bill of lading as security, either has no legal meaning or to agree that this term means a pledge in the general civil sense. The inappropriateness of the first proposal indicates that the pledge, the civil legislation of Ukraine, which regulates the circulation of the bill of lading, means the pledge in the general civil sense (Makovskaya 2000).

Fifth, the registration of the legal relationship of the pledge by the pledging endorsement leaves a pledger mortgagor the opportunity to protect their rights in case of breach of the pledgee's obligations, because the bill of lading secured by a pledging endorsement passes to the pledgee. A pledger does not receive any confirmation of registration of legal relations of the bill of lading. Thus, a pledging endorsement does not mediate the legal relationship of the pledge, but only refers to the relevant rules of civil law of Ukraine and the terms of the pledge agreement. The legal relationship of the pledge is established only outside the obligations arising from the bill of lading. From all the above it can be concluded that a pledging endorsement in itself is neither a pledge agreement of the bill of lading nor its form. Moreover, in the authors; opinion, it cannot be considered as a basis for the emergence of pledging relations. Therefore, in order for the pledgee to equally enjoy the rights granted to him by the civil legislation of Ukraine on the pledge and the legislation governing the circulation of the bill of lading, in addition to making a pledging endorsement, separate drafting of the pledge agreement is required. Legal registration of the transfer of a bill of lading as a pledge is carried out depending on the form of realisation of the right expressed in the bill of lading.

Thus, even M. Agarkov (1994) noted that the pledge of security occurs differently, depending on whether the security is a registered security, bearer security, or warrant security. The diversity in the pledge of registered, bearer and warrant securities are mainly due to differences in the order of transfer of rights to such securities. When a bill of lading is transferred to a bearer, there are no legal conflicts, because, in order to transfer to another person the rights certified by this paper, it is sufficient to hand it over to that person. "The right to anonymous papers arises with the acquisition of the right to a document" (Nersesov 2000). This indicates that the transfer of property rights to the bill of lading occurs at the time of transfer of this paper to its new owner.

A more complicated situation occurs with the pledge of registered and warrant bills of lading. Unlike other objects of civil law, the transfer of which is pledged on the basis of the relevant civil law agreements, the rights certified by the registered and warrant bill of lading are transferred by drawing up a separate bill of lading agreement and is made by entering in its text. Even more problematic is the issue of pledge of an undocumented bill of lading. The transfer of an undocumented bill of lading is carried out by opening a securities account in the name of a pledgee, which accounts for the rights to the undocumented bill of lading, in accordance with the Law of Ukraine "On the National Depository System of Ukraine" that belongs to a pledger.

This account records the deposited undocumented bills of lading, which are pledged. In accordance with paragraph 2 of Article 7 of this law on the securities account, which considers the rights to securities, restrictions are imposed on these securities. Thus, in accordance with Article 17 of the Law of Ukraine "On Pledge", a pledger may alienate the pledged property only with the consent of a pledgee, subject to the transfer to a new pledger of the principal debt secured by collateral. In addition, in accordance with Article 18 of this law, a pledger is obliged to notify each of the pledgees of all previous pledges, as well as the nature and number of obligations secured by these pledges. A pledger is obliged to reimburse the losses incurred by any of his pledgees as a result of his failure to fulfil this obligation (Law of Ukraine... 1992). On the other hand, the pledgee has no right to dispose of the subject of the pledge, except in cases established by the Law of Ukraine "On Pledge", such as: a pledgee acquires the right to recover the subject of a pledge only if at the time of performing obligation, it will not be executed (Article 20) (Law of Ukraine... 1992).

\section{FEATURES OF THE FORECLOSURE PROCEDURE ON THE PLEDGED BILL OF LADING}

One of the main issues that arise when pledging securities is the issue of foreclosure on the pledged bill 
of lading. According to Article 1 of the Law of Ukraine "On Pledge", by virtue of the pledge, a creditor (pledgee) has the right in case of default by a debtor (pledger) secured by the pledge obligation to obtain satisfaction from the value of the pledged property (Law of Ukraine... 1992). Since securities are movable property, in accordance with the rules of the Civil Code of Ukraine, recovery is carried out both in court and out of court. In this case, the means of foreclosure on the mortgaged property may be different:

1. Acquisition by a pledgee of the pledged bill of lading in the property. A pledgee acquires the right to apply for foreclosure on the subject of the pledge if, at the time of the term of performing the obligation secured by the pledge, it will not be performed, unless otherwise provided by law or contract (Article 20 of the Law of Ukraine "On Pledge").

2. Sale of pledged property through auctions (public bidding). Pledged property is sold by specialised organisations for auctions (public auctions) unless otherwise provided by a contract. If the auction (public auction) is declared unsuccessful, a pledgee with the consent of a pledger has the right to keep the mortgaged property for the initial assessment (Article 21 of the Law of Ukraine "On Pledge"). According to Art. 48 of the Law of Ukraine "On Enforcement Proceedings" to ensure the recovery of pledged property the procedure of arrest and seizure of property of a debtor.

3. Exercise by a pledgee of the rights certified by the pledged security (Article 60 of the Law of Ukraine "On Enforcement Proceedings" (2016)).

The current legislation of Ukraine provides the possibility of a claimant to keep the unsold property. In this case, he is obliged within 5 days from the date of notification of the state executor about a desire to keep the unsold property, to make a deposit to the account of the State Executive Service in the amount of the difference between the value of the unsold property and the amount to be recovered in his favour, if the value of the unsold property exceeds the amount of debt to be recovered under the executive document. The state executor draws up an act on the transfer of property to the debt collector to repay the debt, which is the basis for further registration by the debt collector of the ownership of this property. The rights to participate in management, income, etc., arising from registered securities, in other words, the right of ownership of an uncertificated bill of lading, are exercised by a pledgee from the moment of making changes to the register of registered securities holders by foreclosure on the pledged property, based on enforcement inscription of a notary, or a pledge agreement. In this case, the confirmation of ownership of the securities is an extract from the securities account, which a custodian is obliged to provide to an owner of the securities (Law of Ukraine... 2012).

\section{CONCLUSIONS}

Based on the above analysis of the legal aspects of the implementation of the pledge of the bill of lading as security, the following conclusions can be drawn. First, the subject of the bill of lading agreement has certain features. It includes at the same time, not only the cargo but also the right to demand it at the port of destination. Secondly, the emergence of the legal relationship of the bill of lading requires the presence of legally significant actions, such as drawing up a pledge agreement of the bill of lading, as well as making a pledging endorsement on the bill of lading and transfer of the bill of lading to a pledgee. The pledge of the bill of lading is carried out by drawing up a securities pledge agreement and handing over the bill of lading to a pledgee. In itself, a pledge agreement of a bill of lading or a pledging endorsement cannot be considered as a sufficient legal basis for the emergence of a pledge relationship on the bill of lading.

Third, in accordance with the Law of Ukraine "On the National Depository System of Ukraine", the transfer of an undocumented bill of lading is made by opening securities account in the name of a pledgee, which takes into account the rights to an undocumented bill of lading belonging to a pledger and transfer to the appropriate account uncertificated securities. This account records the deposited undocumented bills of lading, which are pledged. Fourth, the current civil legislation of Ukraine on collateral should be supplemented with separate provisions on the pledge of securities. In particular, it is advisable to supplement Art. 53 of the Law of Ukraine "On Pledge" with the provision that undocumented securities are pledged by opening a security account in the name of the pledgee and their deposit in this account, with restrictions on the circulation of securities that are pledged.

\section{REFERENCES}

Agarkov, Mikhail. 1994. Fundamentals of banking law. The doctrine of securities. Moscow: BEK. 
Aikens, Richard, Lord, Richard and Michael Bools. 2015. Bills of lading. London: Informa Law from Routledge.

Baatz, Yvonne. 2020. Maritime law. London: Informa Law from Routledge. https://doi.org/10.4324/9781003046943

Belov, Vadim. 1996. Bill of exchange legislation of Russia. Moscow: Yurlnfo.

Biswas, Liton. 2011. A discussion and analysis of the bill of lading as a document of title. https://doi.org/10.2139/ssrn.2089523

Budilov, Vladimir. 1993. Pledge law of Russia and Germany. St. Petersburg: Farvater.

Civil Code of Ukraine. (2003). https://zakon.rada.gov.ua/laws/ show/435-15\#Text.

Dobrynina, Larisa. 1998. Bill of exchange law of Russia. Moscow: Spark.

Dubovec, Marek. 2006. "The problems and possibilities for using electronic bills of lading as collateral". Arizona Journal of International and Comparative Law 23(2). Retrieved November 17, 2020 (https://ssrn.com/abstract=2135246)

Gabov, Andrei. 1999. Promissory note in the system of Russian securities. Moscow: Institute of Legislation and Comparative Law under the Government of the Russian Federation.

Goldby, Miriam. 2008. "Electronic bills of lading and central registries: What is holding back progress?" Information and Communications Technology Law 17(2): 125-149. https://doi.org/10.1080/13600830802239381

Krasheninnikov, Evgeniy. 1999. "Pledge of a bill". Economy and Law 4: $43-48$.

Law of Ukraine No. 1404-VIII “On Enforcement Proceedings". 2016. Retrieved November 10, 2020 (https://zakon.rada.gov.ua/ laws/show/1404-19\#Text)

Law of Ukraine No. 2654-XII "About the pledge". 1992. Retrieved November 10, 2020 (https://zakon.rada.gov.ua/laws/ show/2654-12\#Text).

Law of Ukraine No. 5178-VI "On the National Depository System of Ukraine". 2012. Retrieved November 13, 2020 (https://zakon.rada.gov.ua/laws/show/5178-17\#Text)
Makovskaya, Aleksandra. 2000. Pledge of securities. Moscow: Statut.

Nersesov, Nerses. 2000. Selected works on representation and securities in civil law. Moscow: Statut.

Netishinskaya, Lyubov, Mokhovaya, Lyudmila, Shekhovtsova, Anna, and Viktoria Kolesnikova. 2018. "The content and form of the pledge agreement in the civil law of the Russian Federation". Journal of Legal, Ethical and Regulatory Issues 21(3): article number 2.

Ning, Zhou. 2003. "The legal nature of bill of lading". China Water Transport 3: 43-47.

Novoselova, Lyudmila. 2004. Bill of exchange in the economic turnover: commentary on the practice of consideration of disputes. Moscow: Statut.

Pratt, Anna and Jessica Templeman. 2018. "Jurisdiction, sovereignties and Akwesasne: Shiprider and the re-crafting of Canada-US cross-border maritime law enforcement". Canadian Journal of Law and Society 33(3): 335-357. https://doi.org/10.1017/cls.2018.26

Schmitz, Torsten. 2011. "The bill of lading as a document of title". Journal of International Trade Law and Policy 10(3): 255280. https://doi.org/10.1108/14770021111165526

Soyer, Baris. 2016. Emergence of EU maritime law. In: A Companion to European Union Law and International Law (pp. 427-437). New York: John Wiley \& Sons, Inc. https://doi.org/10.1002/9781119037712.ch28

Spanjaart, Michiel. 2018. The endorsement of bills of lading. https://doi.org/10.2139/ssrn.3269133

Vyhovsky, Oleksandr. 2003. "Mortgage endorsement in promissory note law: problematic issues". Enterprise, Economy and Law 6: 35-39.

Wunderlich, Stefan and David Saive. 2020. "The electronic bill of lading: Challenges of paperless trade". Advances in Intelligent Systems and Computing 1010: 93-100. https://doi.org/10.1007/978-3-030-23813-1 12

Zekos, Georgios. 2018. E-bills of lading contracts in global transportation. Hauppauge: Nova Science Pub, Inc.

\section{DOl: https://doi.org/10.6000/1929-4409.2021.10.44}

(C) 2021 Haliantych et al.; Licensee Lifescience Global.

This is an open access article licensed under the terms of the Creative Commons Attribution Non-Commercial License (http://creativecommons.org/licenses/by-nc/3.0/) which permits unrestricted, non-commercial use, distribution and reproduction in any medium, provided the work is properly cited. 